\title{
Distended abdomen due to a pseudocyst around a ventriculoperitoneal shunt
}

\author{
Sascha Meyer (D) - Sogand Nemat · Stefan Linsler · Johannes Bay · Michael Zemlin · Martin Poryo
}

Received: 19 April 2021 / Accepted: 23 June 2021 / Published online: 2 August 2021

(C) The Author(s) 2021

\begin{abstract}
Summary Described herein is a case of distended abdomen in a 4-year-old boy with a ventriculoperitoneal (VP) shunt due to bilateral intraventricular hemorrhage following premature birth. Physical examination and laboratory tests revealed tenderness in the lower quadrants, with mild leukocytosis and normal C-reactive protein levels. X-ray demonstrated an intact VP shunt catheter but cranial displacement of the large intestine. Ultrasonography confirmed a large pseudocyst around the VP shunt, with extension from the symphysis to the sternum. The distal part of the VP shunt was surgically revised and 2.51 of cerebrospinal fluid were evacuated. The boy made a full clinical recovery. Conventional X-rays, routinely used to confirm or exclude VP shunt continuity, may provide important clues regarding to the etiology of VP shunt dysfunction.
\end{abstract}

Keywords Prematurity · Ventriculo-peritoneal shunt · Abdomen · Cyst · Ultrasonography

Prof Dr. S. Meyer, MD (四) · J. Bay · M. Zemlin

Building 9, Department of Pediatrics and Neonatology, University Medical Center of Saarland, 66421 Homburg, Germany

sascha.meyer@uks.eu

S. Nemat

Department of Radiology, University Medical Center of

Saarland, Homburg, Germany

\section{S. Linsler}

Department of Neurosurgery, University Medical Center of Saarland, Homburg, Germany

\section{Poryo}

Department of Pediatric Cardiology, University Medical Center of Saarland, Homburg, Germany

\section{Case report}

This case report describes a 4-year-old boy with a history of bilateral intraventricular hemorrhage requiring the insertion of a permanent ventriculoperitoneal (VP) shunt after being born as premature infant after 28 weeks of gestation. Upon admission to our hospital, the parents reported recurrent vomiting, but no fever or diarrhea.

On physical examination he looked unwell, and on palpation the abdomen was distended and demonstrated tenderness in both lower quadrants. The VP shunt could be easily palpated, with no signs of discontinuation. Laboratory analysis showed mild leukocytosis but C-reactive protein within the reference range.
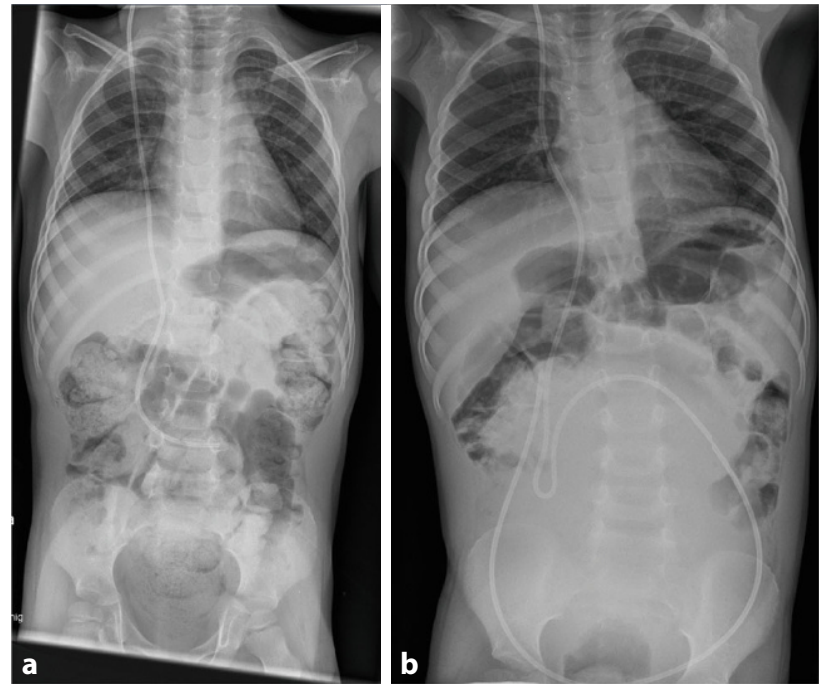

Fig. 1 a X-ray demonstrating cranial displacement of the large intestine, $\mathbf{b}$ X-ray demonstrating regular intra-abdominal gas pattern 


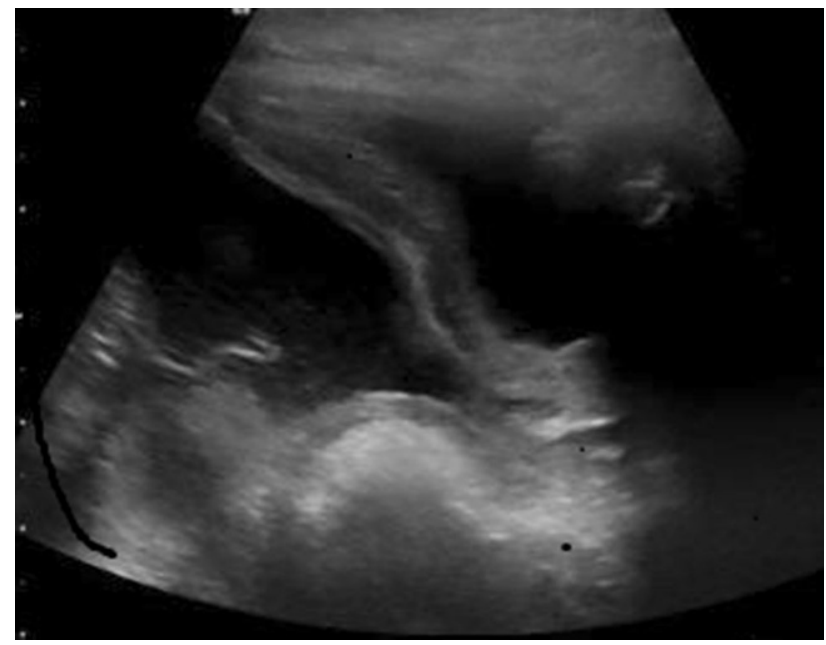

Fig. 2 Ultra-sonography showing large intra-abdominal pseudocyst

To rule out VP shunt disconnection, an X-ray study was performed demonstrating an intact VP shunt catheter but cranial displacement of the large intestine (Fig. 1a), most notably when compared to a previous examination (Fig. 1b; with a different VP shunt).

On ultrasonography, a large pseudocyst around the VP shunt was confirmed, with extension from the symphysis to the sternum (Fig. 2). Subsequently, the distal part of the VP shunt was surgically revised and $2.5 \mathrm{l}$ of cerebrospinal fluid were evacuated. After surgical revision, the boy made a full clinical recovery.

We conclude that conventional X-rays-although routinely used to confirm or exclude VP shunt continuity-may provide important clues with regard to the etiology of VP shunt dysfunction [1, 2].
Author Contribution All authors were involved in patient care and were responsible for drafting the manuscript.

Funding Open Access funding enabled and organized by Projekt DEAL.

Conflict of interest S. Meyer, S. Nemat, S. Linsler, J. Bay, M. Zemlin, and M. Poryo declare that they have no competing interests.

Open Access This article is licensed under a Creative Commons Attribution 4.0 International License, which permits use, sharing, adaptation, distribution and reproduction in any medium or format, as long as you give appropriate credit to the original author(s) and the source, provide a link to the Creative Commons licence, and indicate if changes were made. The images or other third party material in this article are included in the article's Creative Commons licence, unless indicated otherwise in a credit line to the material. If material is not included in the article's Creative Commons licence and your intended use is not permitted by statutory regulation or exceeds the permitted use, you will need to obtain permission directly from the copyright holder. To view a copy of this licence, visit http://creativecommons.org/licenses/by/4.0/.

\section{References}

1. Basilotta Márquez YNI, Mengide JP, Liñares JM, SaenzA, ArgañarazR, Mantese B. Abdominal complications in patients with a ventriculoperitoneal shunt: proposal for management recommendations from a single pediatric tertiary center. Childs Nerv Syst. 2021; https://doi.org/10.1007/ s00381-021-05121-y.

2. Guest BJ, Merjanian MH, Chiu EF, Canders CP. Abdominal cerebrospinal fluid pseudocyst diagnosed with point-ofcare ultrasound. Emerg Med. 2019;3(1):43-6. https://doi. org/10.5811/cpcem.2018.11.40780.

Publisher's Note Springer Nature remains neutral with regard to jurisdictional claims in published maps and institutional affiliations. 